\title{
"Better Dead than Communist!" \\ Contentious Politics, Identity Formation, and the University Square Phenomenon in Romania
}

JULIA BROTEA AND DANIEL

BÉLAND

\begin{abstract}
The 1990 protest episode known as the University Square Phenomenon constituted a crucial and contentious episode for Romania's political transition from communism. Analysis of this incident sheds light on the long-term consequences political protests can have when they translate into routine politics. More specifically, such an analysis enriches the emerging literature on "how social movements matter" by underlining the lasting impact of the University Square Phenomenon on Romania's party system and political culture. Drawing in part on the theoretical framework presented in Doug McAdam, Sidney Tarrow, and Charles Tilly's Dynamics of Contention, the analysis of the University Square focuses on two major processes: identity formation and contentious repertoires. This examination shows that the political identity gained during the University Square Phenomenon and the repertoire for political protest it generated played a decisive role in its aftermath and the naissance of a democratic civil society in Romania.
\end{abstract}

\section{INTRODUCTION[1]}

In contrast with other Eastern European countries, Romania witnessed a violent exit from communist dictatorship. More than 1,000 people were killed in the December 1989 Revolution and, in the first half of 1990, many opposed the participation of a neo-communist elite in the first democratic elections in more than five decades. It was at this moment that a crucial yet understudied episode of political contention took place: the University Square Phenomenon. This episode constituted an attempt to liquidate Romania's communist legacy and move towards a genuinely democratic order. The protest was sparked by a meeting organized on April 22, 1990, in Bucharest's University 
Square, marking exactly four months after the 1989 Revolution. The intention of this protest was to adopt legal measures preventing corrupt former elites from running for office and from holding public functions. A direct corollary of this demand was the deterring of the Front for National Salvation (FNS) - a self-proclaimed provisional government with strong links to the former Communist Party — from running in the May 1990 election. Large-scale discontent and fear of the FNS (felt especially by intellectuals) contributed to the rapid transformation of this protest episode. Its growth in intensity and duration allowed the protesters in University Square to become a symbol not only of the struggle against neo-communism but also of early Romanian democratization. The University Square Phenomenon gave rise to long-term, ongoing political outcomes in post-1989 Romania. For example, it contributed, albeit indirectly, to the victory of the Democratic Convention of Romania (DCR) in the 1996 election and it generated a repertoire of contention that can now stand on its own. Today, the University Square Phenomenon symbolizes an episode of contentious politics that acted as a catalyzing force for the Romanian opposition, helping it reorganize itself and eventually win the 1996 election.

From this perspective, the University Square Phenomenon points to a major theoretical question present in the current political sociology literature: "how do social movements matter?" Although crucial, this question has received relatively little systematic attention in the relevant social science literature (Giugni et al. 1999). In order to explore this question while reconstructing the development and the aftermath of a major yet understudied contentious episode, the following article analyses the role of identity formation and contentious repertoires in the different phases of the University Square Phenomenon before exploring its long-term consequences on contemporary Romanian politics and society. The discussion about the contentious episode itself focuses on these two processes, i.e. identity formation and contentious repertoires, because they are most relevant for the examination of long-term outcomes and easy to trace in the aftermath of the protest. This approach is derived in large part from Dynamics of Contention, and it has the added benefit of recreating the original dynamic context in which the identity of the University Square Phenomenon emerged as well as the repertoire of contention it made available for adaptation in subsequent protest years. This article concludes with a discussion about the broad social and political implications of the University Square Phenomenon through an exploration of the link between this episode, democratization, and potential "revolutionary trajectories" in the early 1990s. 


\section{HOW CONTENTIOUS EPISODES CAN MATTER}

McAdam, Tarrow, and Tilly's Dynamics of Contention has been described as "the most ambitious, and arguably the most important, book on social movements (and related phenomena) written in the past two decades" (Tindall 2003: 408; Mische 2003; Peterson et al. 2002). The main objective of this book is to provide scholars with new insights into various forms of "contentious politics." According to the authors, contentious politics involves widespread - and potentially transgressive - social mobilization. Contentious politics is different from routine politics, which gravitates around well-established bureaucratic, political, and electoral rules.

Dynamics of Contention proceeds to stress the similarities that exist within a wide range of contentious episodes and to focus on the parallels that exist among them. The present article takes a similar approach, countering the criticism of Dynamics of Contention that it cannot be employed in further studies because, "in the absence of a deductive structure it is practically impossible to judge which theoretical claims make logical sense, and which do not. Furthermore, it is difficult to build and extend theory" (Tindall, 2003: 486). Instead, the current analysis shows the helpfulness of the authors' approach to understanding the University Square episode of contention, which falls outside the scope of grand, overarching theoretical models for revolutions and for democratization, although it does exhibit elements of both.

Two issues discussed in Dynamics of Contention will be at the center of this study: identity formation and contentious repertoires. These issues have been selected among the list of mechanisms and processes discussed in this book because they are especially central for emphasizing the long-term impact of the University Square Phenomenon on Romanian politics and society.

The most radical example of identity formation comes from the French Revolution and the affirmation that "the source of all sovereignty resides essentially in the nation," which all modern republics have. As the French Revolution also illustrates, identity, which emerges from a social movement, is not a constant but rather the result of an interactive process (McAdam et al. 2001). This process is related to a number of causal mechanisms important for this study: category formation, object shift, and certification. First, actors frequently link previously unrelated social sites generating "new boundaries and connections among political actors," (McAdam et al. 2001: 142), which lead to the emergence of original social and political categories. In turn, the formation of such categories has a major role to play in the 
consolidation of new political identities. Second, the actions that take place following the genesis of a new political identity can generate an "object shift": a displacement of the object of social and political claims that affects the original repertoire of contention. Finally, the certification of actors by external authorities such as foreign states and international organisations is the third recurring mechanism of identity formation. The lack - or the withdrawal — of external recognition can undermine the legitimacy as well as the mobilising capacity of social and political actors involved in episodes of contention (McAdam et al. 2001: 142-6). This brief discussion of the three "identity-transforming mechanisms" shows that collective identities change during mobilisation processes, sometimes in a sudden manner, and that identity formation also involves the appropriation of existing identities. In addition, following a logic described by Benedict Anderson (1991), it involves a selective memory and interpretation of the past in order to create an image of cohesiveness amongst participants. Finally, identities created during such episodes later impact routine politics: "creation, transformation, and extinction of actors, identities, and forms of action in the course of contention alter the array of actors, identities, and actions that appear in routine politics and further contention once the particular episode of contention has ended" (McAdam et al. 2001: 56). And, while an ideology or an economic grievance can fuel the creation of a new political identity such as the proletariat's or the British labour strikes, it does not have to. As the analysis of the University Square Phenomenon shows, protesters can also be fuelled by an inherent notion of justice. The University Square Phenomenon sprang from the realisation that the Romanian Communist totalitarian regime was unjust and that the 1990 government was not committed to uprooting its vestiges but rather had demonstrated that it would continue on a similar path.

The process of identity formation is aided by repertoires of contention, which imply that social and political mobilization involves a set of symbols and codified rituals. Although their impact is variable in scope, these symbols can become a major component of identity construction processes. This is true largely because repertoires of contention are embedded in historical memory. For example, Hannah Arendt writes on the topic of the spirit of the revolution that "there is nothing that could compensate for its failure or prevent it from becoming final, except memory and recollection. And since the storehouse of memory is kept and watched over by the poets, whose business it is to find and make words we live by (...) these reflections are significant enough as they testify to the involuntary self-discourse, to the joys of appearing in word and deed without equivocation and 
without self reflection that are inherent in action" (Arendt 1990, 2801). Thus, according to Arendt, the preservation through culture of a revolutionary repertoire can provide a political body with the necessary resources to mobilise resistance against the onset of tyrannical rule. In the study of social movements the concept of repertoire has been widely discussed (e.g. Tarrow 1994, Tilly 1986). Yet, Dynamics of Contention gives an additional dynamic meaning to this idea, which could wrongly suggest a stable set of tools and symbols that seldom evolve over time. In response to their circumstances, social and political actors rework known routines and symbols available to them. Contentious repertoires feature routines that are modified over and over again. Furthermore, in order to reinforce the interactive aspect of repertoire, the authors define the concept of contentious repertoires as "limited ensembles of mutual claim-making routines available to particular pairs of identities" (McAdam et al. 2001: 138). Actors "borrow a theatrical metaphor - repertoire - to convey the idea that participants in public claim-making adopt scripts they have performed before" (McAdam et al. 2001: 138). Similar to identity formation, appropriation and interaction are also central to the working and reworking of contentious repertoires. Our analysis stresses this logic through the study of the slogans, songs, and general claims put forward in the context of the University Square Phenomenon as well as the manner in which the actual University Square location continued to remain a site for subsequent minor protests.

Beyond the study of identity formation and contentious repertoires, the following empirical section ends with a discussion about democratization and "revolutionary trajectories" as discussed in Dynamics of Contention. Although "revolutionary trajectories" seemed to materialize during the development of the University Square Phenomenon, they were never converted into a revolution. Yet, the absence of an overarching theoretical model ought not to prevent the study of such episodes but rather reinforce the search "for mechanisms that appear variously combined in all (...) forms of contention" (McAdam et al. 74). This search becomes particularly important when, as in the case of University Square, an episode of contention not only fuels the creation of civil society but also the formation of a new political party and its subsequent electoral victory.

This discussion about the impact of the University Square Phenomenon leads to the issue of "how social movements [and contentious episodes] matter." Despite recent attempts to explore such issues (Amenta 2006; Amenta and Caren 2004; Giugni 1998), one can still argue that "the study of the consequences of social movements is one of the most neglected topics in the literature. (...) [W]e need more 
systematic studies that can shed light on various aspects of movement impact, in particular on the potential consequences, on the conditions and circumstances that favour certain consequences as well as the processes leading movements to have an impact, and on the actual effects obtained by past as well as contemporary movements" (Giugni et al. 1999: xv). The most realistic, long-term impact of social movements is the conversion of grievances previously articulated in a setting of contention into routine politics. This transformation into routine politics is usually carried out by the reorganization of protesters into civil society organizations, which continue the protestors' struggle from within the system. An illustration of this process is provided by American feminist groups, which increased in number from 75 in 1982 to 140 in 1995, and which established their presence in Washington, D.C., from where they advanced "a new public policy agenda to mobilize support for legislation" (Gelb and Hart 1999, 153). Yet, as the current analysis of the University Square Phenomenon shows, social movements can surpass other civil society organizations as they transform themselves into political parties and eventually win elections. Furthermore, social movements can affect the political culture of the country in which they operate. In the case of the University Square Phenomenon, this translates into the emergence of powerful anti-communist symbols that are still present in today's Romanian

political culture. These findings about the University Square Phenomenon are especially interesting because they move the analysis beyond the traditional focus on policy outcomes present in the literature to the lasting consequences of social movements and contentious episodes (e.g. Amenta and Caren 2004). They also correspond to Marino Diani's recommendation to concentrate "on the structural position occupied by movement actors after phases of sustained political and/or cultural resistance," in order to observe "whether they facilitate the emergence of new networks, which in turn allow advocacy groups, citizens' organizations, action comities, and even single individuals to be more influential in processes of political and cultural transformations" [emphasis added] (Diani 2001: 209).

\section{UNDERSTANDING THE UNIVERSITY SQUARE PHENOMENON}

Far from presenting a detailed reconstruction of the University Square Phenomenon, the following sections focus on the theoretical elements discussed above. The objective here is to shed light on identity formation and contentious repertoires while underlining the broad social and political impact of this crucial contentious episode in the mirror of the routinization of politics that took place after the episode ended 
with the miners' violent intervention. The chronological structure of the second part reflects the four phases of the University Square Phenomenon: organization, development, aftermath, and consolidation.

\section{Organization: Identity Formation and Repertoires in University Square}

Though the University Square Phenomenon forms an episode of contentious politics on its own, it cannot be approached without a brief overview of the historical and political events leading up to that point. After 45 years of communist rule, the population of Timişoara initiated the Romanian Revolution, which by December 22, 1989, had spread to other cities, particularly Bucharest (Milin 1990). Unlike other Eastern European movements where the overthrow of former communist regimes was peaceful, the Romanian Revolution claimed 1,104 deaths. In the aftermath, the courts, which should have brought those responsible for the December massacre and for the 45 years of communist rule to trial, failed to do so and thus, "the crimes of December 1989 and those of the Communist past remained a running sore on the Romanian body politic" (Siani-Davies 2000: 17). Added to this was Dictator Nicolae Ceaussescu's escape, immediately after which the Front for National Salvation (FNS) formed and made its first public appearance on national television. The most prominent spokesman of the FNS was Ion Iliescu, a former high official of the Romanian Communist Party at the time virtually unknown to the general public, who later became president of the country (Deletant 2000: 35-59; Osmani 1997). Despite the FNS's efforts to deny its connection with the previous Communist Party, it soon became obvious to many Romanians that the party's "anti-communism was of a more recent vintage" (Călinescu and Tismăneanu 1991: 40-59; Hickman 1998: 3). Furthermore, FNS's refusal to outlaw the Romanian Communist Party and the first arrival of miners on January 29 - followed by another group on February 18 - to restore order in Bucharest generated doubts amongst many Romanian intellectuals about the success of the 1989 Revolution (Bellu and Badin, 2005).[2]

Further still, the tumultuous days of late December, in which the FNS proclaimed itself the provisional government, coincided with the time when a new enemy of the Revolution and of the Romanian people - "the terrorists" - made their presence felt. To this day the identities of the terrorists remain unknown, under whose orders they acted, how many people died because of their actions, and why they vanished without a trace only a few days later (Hickman 1998; 
Siani-Davis 2000: 15). These so-called terrorists were evoked in the media (particularly on television) during those days, and they brought with them the old Hobbesian realization that security is more important than freedom. Under these circumstances, the FNS became the government of Romania and Ion Iliescu became president. Soon afterwards, in March 1990, ethnic tensions escalated into violence in Târgu-Mureş, a Transylvanian city where ethnic Hungarians form the majority. The President's reaction to this conflict "raised doubts about Iliescu's commitment to minority rights. [... T] The President's manipulation of state media [particularly the only TV station in existence at the time] before the election of May 1990 raised further doubts about his democratic credentials" (Light and Phinnemore 2000: 2). In response to Iliescu, worker and student association members held a gathering on March 11, 1990, in Timişoara to adopt the Proclamation of Timişoara (Călinescu and Tismăneanu 1991: 53). The Proclamation, written mainly by George Şerban and published by the Timişoara Society (Mungiu 1996: 351) stated: "For the victory of the Revolution, in Timişoara, together with the Romanians, Hungarians, Germans, Serbs and members of other ethnic groups died, who for centuries lived peacefully in our city. [... We] want to live in a country where tolerance and mutual respect are the only principles that will rule the future Europe Home" (Proclamation of Timişoara). The same Proclamation also asserts: "The Revolution was from its first hours, not only anti-Ceauşescu but also, categorically, anti-communist." Of paramount importance was the eighth point in the Proclamation of Timişoara, which proposes: "an electoral law that forbids former communist activists and former Securitate officers for the first three consecutive elections from standing for election on any electoral list (...) and the inclusion of a special paragraph in the law forbidding former communist activists to run for the office of President."

These circumstances prepared the ground for the University Square Phenomenon. Thus, on April 22 the National Peasant Party (NPP), a newly formed political party claiming continuity, via its leaders Corneliu Coposu and Ion Diaconecu, with the pre-war National Peasant Party, organized a meeting of protest "with the intention of deterring Iliescu and other former communist leaders from running in the May 20 election" (Osmani 1997: 3). However, the demonstration did not terminate at the end of the day: protesters blocked University Square with the intention of continuing the struggle against communism that had started with the 1989 Revolution. It is no coincidence that the date chosen for the protest by the NPP was April 22, a day exactly four months after the 1989 Revolution. Hence, those who conceived the Proclamation of Timişoara, as 
well as the NPP, became the first actors of the University Square Phenomenon, while the actual Proclamation articulated a new political category whose pillar was "anti-neo-communism." These elements are best understood in the context of repertoires of contention, where "previously created performances" (Tilly 2002: 118) are borrowed for new purposes. In the case of University Square, the repertoire was only four months old and the slogans that predominated in University Square were, as they had been four months earlier, "Down with the Communists!" to which was added "Down with the Neo-Communists!"

Two days into the demonstration, on April 25, the protesters abandoned the NPP identity in favour of a new "University Square identity" that was to extend from Bucharest throughout the country, and which shared the NPP's opposition to communism, but did not include a genuine political platform for winning the May election. Unlike the NPP, the University Square events were not an attempt to win the election, only to deter FNS from participating in it. In this manner, the protesters could bestow upon themselves a moral role unfettered by long-term electoral motives. The University Square events also brought about unintended consequences by moving beyond the intent of the NPP, by gaining its own identity, and by abandoning political ties with the party that had organized the meeting in the first place. Furthermore, the issue of the May 20 election was pushed to the periphery of their protest while the Proclamation of Timişoara and the anti-communist agenda moved to the forefront. This switch in agenda could have aided the University Square identity formation.

This becomes particularly clear when one compares the University Square Phenomenon with the 1996-97 Serbian student movement, as the two protest movements share some basic features. Yet, the raison d'etre for the Serbian protest was and remained narrow in scope, as it focused on the recognition of the November 17 municipal elections, in which the Zajedno opposition alliance won Belgrade and other major cities. As a result, Slobodan Milošević was able to dismantle the fragile anti-Milošević coalition and put an end to the student protest by simply giving into the opposition's demands (Thompson and Kuntz 2004). Compared to the members of the 1996-97 Serbian student movement, the University Square protesters were less pragmatic; their demands reached beyond short-term political goals and aimed at the overly naïve but morally inspiring process of decommunization and "trial of communism." Thus, the weeks from April 22 to May 20 were sufficient to allow for the emergence of this new political identity, whose main pillar was the struggle against communism and 
contoured around the "categorically against communism" stance of the Proclamation of Timişoara.

Another element that contributed to the consolidation of this new political identity came from the way in which the protesters interpreted the 1989 Revolution. Essentially, the protesters in University Square were challenging the victory that the FNS had proclaimed. Protesters began referring to the University Square Phenomenon as the continuation of the 1989 December Revolution. It was this belief that created for them a "fortifying myth." Part of the motivation behind this interpretation came directly from the Proclamation of Timişoara, which ends with the statement: "We, the authors of this Proclamation, participants at the events from December 16-22, do not consider the Revolution finished. We will continue it firmly. After we faced and triumphed, without anyone's help, in overthrowing one of the most powerful and repressive systems in the world, nobody and nothing can intimidate us." Furthermore, signboards reading "PCR = FSN" (Romanian Communist Party = Front for National Salvation) appeared in University Square, further adding to the sense of continuity between the 1989 Revolution and the current protest. Hence, exactly four months after the Revolution, the people of Bucharest were once again shouting: "Down with the Communists," asserting in University Square that, for them, the 1989 Revolution was continuing and that the battle against the communist regime was still to be won.

The early days of the University Square movement included powerful elements of contention. Most important among these are the repertoires of contention and the emergence of a new political identity that benefited from the way the protesters depicted the Revolution, allowing political legitimacy to pass from the 1989 Revolution to the University Square. The University Square movement formed its new political identity by retaining the same slogans and the same goals of anti-communism from the 1989 Revolution, and by applying them, not to the former Communist Party, but to the newly formed provisional government, FNS. The demonstration organized by the NPP broke allegiance with the party only two days later and became an episode of mass protest with its own identity and remained this way for the following six weeks. In more theoretical terms, the action of breaking allegiance with the NPP marks an "object shift," changing the focus of the protest from the May 20 elections to the anti-neocommunist and anti-FNS. Those same elements of the repertoire of contention and political identity are also present in the subsequent days of the University Square but in a slightly different form as the political identity of the University Square gained a bolder contour. 


\section{Development: What was the University Square Phenomenon?}

Two days into the University Square Phenomenon, the protesters declared themselves to be peaceful, multicultural (they included Hungarians and other ethnic minorities), anti-communist, and anti-neocommunist. They also broke their allegiance with the NPP, who had organized the meeting on April 22. Dr. Emil Constantinescu, acting president of the University of Bucharest and professor at the Department of Geology gave protestors the right to use department's balcony (Dabija, 2007), which "became the tribune from which personalities or average citizens demanded the democratization of the country" (Gheorghe and Huminic 1999). On April 24, in a Provisional Council for National Unity (PCNU) meeting, President Ion Iliescu called those in University Square golani (thugs), a label rapidly embraced by the demonstrators who, in addition to calling themselves golani, baptized the perimeter they occupied in University Square Golania (Thug Land) (Gheorghe and Huminic 1999). This was a particularly poor choice of words for President Iliescu because only four months earlier former dictator Ceauşescu had referred to the protesters who initiated the 1989 December Revolution in Timişoara as hooligans. This new name was quickly stripped of its derogatory connotation and became a badge of honour as many "Cambridge, Sorbonne, and Oxford students declared themselves 'thugs.'" Romanian dramaturge and member of the French Academy, Eugène Ionesco, proclaimed himself an "academician thug," while other prominent intellectuals were granted the title of "honorary thug" (Mungiu 2003: 351; Cesereanu 2003). Thus, the identity of the University Square was initially contoured around very nebulous symbolism but continued to grow through intense interaction among the protesters.

This identity consolidated even further as some of the golani decided not to leave the Square, setting up tents, claiming the University Square area as a "zone free of neo-communism" (Tismăneanu 1990: 16-19) and calling the place "the 'kilometre zero' of freedom and democracy." By doing so the protesters not only made public claims according to their identity but also made clear they regarded the provisional government as an object of contention (McAdam et al. 2001: 134). University Square was entirely transformed by the protesters and gained "a somewhat desolate aspect during the day (being populated mostly by those on hunger strikes, ardent protesters, and some indolent ones), [while] the protests began in the afternoon and gained proportions in the evening and at midnight, when the spectacle shut down by itself"(Cesereanu 2003). 
Cesereanu was right to describe the protest as "animated" and as a "spectacle." The University Square was in many ways a cultural event where artistic expression in the form of slogans or songs served the moral and political goals of the protesters. Their signs exclaimed, for example, "Yesterday hooligans, today thugs," "Today in the capital, tomorrow in the whole country," "We do not go home, the dead won't let us," and "We will die but we'll be free." Along the same lines, songs were composed with the purpose of building continuity with the 1989 Revolution and of overthrowing the FNS government. Most of the songs and slogans accused the present government of the same charges as the 1989 Revolution had the former dictatorial government. The gravest of these was the murder of innocent people, particularly the killing of over 1,000 people during the 1989 Revolution. This accusation was articulated in the lyrics: "God, come God / to see what's left of humans (...) / There are nights long and sad (...) / And you don't even care about those who are not / Those who accuse you from there, from their graves" (Sterian 1990: Line 1, 4, 24). These slogans and songs established a spiritual continuity between the 1989 Revolution and the University Square events of the following year. The University Square movement even adopted its own anthem, "Anthem of the Golani," whose lyrics were sung from the Geology Department's balcony with the crowd joining in from below: "Better hoodlum, than traitor / Better golan than dictator / Better hooligan than activist / Better dead than communist!" As Steinberg pointed out, as in the case of the Serbian student movement, popular music also served "as a vehicle for sustained social and political challenge" in the University Square events (Steinberg 2004). This cultural expression gave the University Square events a sense of spectacle while also framing the protesters' social and political identities, allowing them to protest against the NSF government. If, as the authors of Dynamics of Contention argue, political identities figure in both routine social life and contentious politics, the identity that developed in University Square clearly belongs to the "political identities [which] originate or specialize in contention" (McAdam et al. 2001: 135). Furthermore, during this period University Square's identity gained a bolder contour and clarity in its scope, being categorically anti-communist and opposed to the current government.

In the case of the University Square this observation reveals that the protesters interacted with each other and renegotiated an identity independent from the political party with which they had once had allegiance. They first adopted the new University Square political identity and then developed an allegiance to this same identity. In addition, they adjusted the boundaries they occupied and, as stated 
above, called the University Square a "zone free of neo-communism" and Golania (Thug Land). The protesters in University Square modified their actions in rapid response to the political environment; they chose the 1989 Revolution as their script and modified it to fit the new political requirements. Thus, they improved new forms of collective action and spoke words no one had uttered before. Simultaneously, they responded to their location within the web of social relations that University Square embodied. The University Square Phenomenon adds support to the claim that "social construction occurs (...) socially and not in isolated recesses of individual minds" (McAdam et al. 2001: 135), and that a new political identity can emerge from a protest movement through political interaction.

This political identity became even more perceptible in the actions of University Square intellectuals such as Ion Caramitru, Ana Blandiana, Octavian Paler, Gabriel Liiceanu, Ovidiu Iuliu Moldovan, Nicolae Manolescu, Marian Munteanu, Dan Haulica, and notably, Emil Constantinescu, who acted as representatives for the University Square and asked President Iliescu to accept a dialogue between the government and the protestors, which Iliescu refused (Cesereanu 2003). Moreover, they took upon themselves the moral role of "organizing hope." In Octavian Paler's words: "[i]n December I set aside my usual scepticism and allowed myself to believe that my country was on the brink of a democratic future. But my hopes were crushed (...) Andre Malraux once said that to arrive at courage one has to organize hope; that's what we will have to do, organize our hopes" (Paler 1990: 12). Still, the intellectuals' roles at that instance can be defined as actors for the newly created identity of the University Square. Furthermore, these people came to be identified as the principal actors of the University Square through the interviews and editorials they published in support of the University Square Phenomenon (Roşca 1996). These individuals, some of whom had not been prominent public figures before the University Square, bestowed upon themselves "moral evaluations and responsibilities" (McAdam et al. 2001: 131) that they were expected to confirm even after the University Square had ended. This moralistic component made the University Square actors not only a symbol of the opposition to the NSF and to communism, but it also made them, in the eyes of the protesters, symbols of liberaldemocratic values. As became obvious after the election of their chosen presidential candidate, Emil Constantinescu, in 1996, the coalition associated with the University Square legacy had difficulties rising to their own high moral and political standards.

The people mentioned above acted time and again as spokesmen, defenders, and supporters of the University Square, taking upon 
themselves the task of articulating answers to the questions "What is the University Square?" and "What does the University Square claim?" At the beginning of the University Square matters were less complicated and the questions were even answered in song: "You ask us why we're here? / But the entire country knows / We support the eight point from Timişoara" (Cesereanu 2003). However, the extended time-span of the University Square demonstration called for new proposals and explanations for the continuing marathon protest, which had supporters, although in much smaller numbers, in other cities of the country (Roşca 1996). Actors were required to express the University Square's newly formed political identity. It is not surprising that these actors had to be autochthons to the University Square, particularly because they could no longer be members of political parties but rather could only speak - and stand - in University Square as private individuals. While these actors remained consistent with the University Square's goal of being independent of any political party, and while they also spoke at length about "the purity of the University Square and about its apolitical character" (Roşca 1996), they did not unite around a common political platform, and, as a consequence, neither could the mass of people of gathered in University Square. The election of May 20, 1990, held after one month of marathon protest, found the political identity of the University Square formed, but without being articulated in a political party, it was politically inoffensive.

\section{Aftermath: The End of the University Square and the "Revolutionary Situations" Issue}

The election results of May 1990 proved to be catastrophic for the University Square protesters: with an $86.19 \%$ turnout, the FNS garnered $85 \%$ of the popular vote, while the opposition votes were scattered among 73 parties plus other independent candidates. Part of their failure was because the University Square had not been able to include every social class into their movement, with the majority of the protesters being students and intellectuals (Mungiu 1996: 352) and most of them from Bucharest. While this is an important factor for explaining the electoral defeat, the most crucial one was articulated by Nicolae Manolescu, a member of the DCR: "We did not lose because of fraud but because we were unable to convince the Romanian electorate that we were better than the others" (Roper 2000: 75).

Following the election "the majority of formations that participated in the University Square (Association 21 December, The Students' League, The Group for Democracy, etc) retreated. (...) Thus, 
through this reflux, the University Square was emptied by a considerable part of its Golani" (Tismăneanu 1990: 18). The remaining protesters had to face not only the police forces but also the miners.[3] At this point, however, the protestors' apparent legitimacy vanished entirely as foreign newspapers, as well as some of the local ones, claimed that democracy meant recognizing the elected government. This reality illustrates the role of certification in contentious politics: in the absence of external support and recognition, political protests seem less legitimate. In the case of the University Square, such a decline in legitimacy rapidly undermined social and political mobilization.

Yet, a small number of protesters remained in University Square. On June 11, Iliescu agreed to engage in negotiations with them but the negotiations quickly failed. By June 15-16, newly elected President Iliescu, "instead of using the legal tools at his command, appealed [on public television] to an extralegal force, the coal miners, giving them his presidential blessing to exert unbounded terror" (Tismăneanu 1990: 3, Vasi, 2004). He thus "unleashed (...) thousands of coal miners armed with hammers and bats, some visibly intoxicated, who descended upon the protesters and innocent bystanders" (Osmani 1997: 4). Though the miners' eruption constitutes a contentious episode of its own, for the purpose of this study it also marks the violent end of the University Square events. The protesters that remained were beaten with bats, some of the offices in the Department of Geology were destroyed, six people were killed, and more than 560 hospitalized (Gheorghe and Huminic 1999; Vasi, 2004).

The University Square protest falls among the cases that feature many elements of contention but that do not develop into a revolution. According to McAdam, Tarrow, and Tilly, "few successful cases result from a large sample of revolutionary situations (McAdam et al. 2001: 195). Although the University Square Phenomenon never evolved into a genuine revolution, three typical "revolutionary situations" were present. First, "the appearance of contenders (...) advancing exclusive competing claims to control the state, or some segment of it" (McAdam et al. 2001: 197), materialized from April 22 onwards in the University Square Phenomenon, as it grew in numbers reaching almost 300,000 protesters in Bucharest alone (Mungiu 1996: 352). Second, the "commitment to those claims by a significant segment of the citizenry" (McAdam et al. 2001: 197) was also present, especially because many protesters belonged to the social, political, and cultural elites of Romania. Third, "the incapacity or unwillingness of rulers to suppress the alternative coalition" (McAdam et al. 2001: 197) also occurred for most of the duration of the University Square Phenomenon. Iliescu did not take action to stop the protest until well after the 
May 20 election -only on June 13 after most of the University Square protesters had left (only about 250 remained) did the miners intervene (Gheorge and Huminic 1999). Despite the coincidence of these three revolutionary elements, however, the University Square Phenomenon was not successful in continuing the 1989 Revolution, nor was it able to initiate a new one. What made the difference in the University Square was, above all, the election of May 20, 1990. It was Romania's first democratic election in more than fifty years, and the result could not be compromised because, after all, the University Square, first through the Proclamation of Timişoara and later through the articulation of its main actors, had always declared itself in accordance with democratic principles. In a way, the University Square did not become a full-blown revolution largely because, after May 20, it would have become an anti-democratic mobilization incompatible with its proclaimed democratic goals.

\section{Consolidation: How the University Square Phenomenon Mattered}

The concrete impact of social movements and contentious episodes should not be assessed exclusively in the mirror of their explicit political goals. Even if a protest episode fails to reach the goals of its organizers and participants in the short run, its long-term effects can have a considerable bearing on subsequent political development in terms of policy outcomes as well as "broader and usually more durable systematic changes, both on the structural and cultural levels" (Giugni et al. 1999: xxi-xxiii).

In Romania, the end of the University Square Phenomenon, which culminated with the miners' violence, brought about two cold realizations. First, despite the connection the FNS had with the former communist leadership, they won the elections democratically and with an overwhelming majority. Second, the election made it obvious that the opposition served the role of an opposition only in principle. In practice the political opposition was virtually non-existent because it was not able to present an alternative to the NFS. In response to this during the fall of 1990 "discussions [took] place for the organization of a civil movement in Romania," and on November 7 the Civic Alliance was formed de facto (Civic Alliance). In this regard, comparable similarities exist with the Serbian student movement, which proved to be another catalyst for the formation of civil society organisations, most notably Otpor. Otpor ran as a political party in the 2003 Serbian election but registered a mere $1.6 \%$ of the popular vote. It did, however, become an influential international civil society organization promoting student resistance to undemocratic rule throughout Eastern 
Europe. In the case of the University Square, the civil society organizations remained more local in focus. Thus, the motto of the Civic Alliance became "we can only succeed together," and Marian Munteanu, a figure who distinguished himself during the early days of the University Square Phenomenon, was elected president of the organization. One year later in July, Anna Blandiana became next president of the Civic Alliance. Blandiana had been nicknamed an "honorary thug" during the University Square. Simultaneously, Emil Constantinescu, former Geology professor at the University of Bucharest and prominent speaker in "Thug Land," became vice-president of the Civic Alliance. The appearance of the Civic Alliance was hailed as being "born directly from the University Square with the goal of supporting the process of democratization, and it marked the moment when the intellectuals began to understand the necessity of political involvement for the creation of a democratic society" (Tariuc 1998: 7, Alianta Civica). Following a "white march" organized on July 13 to demand the release of those arrested on June 11-13, Anna Blandiana confessed "I thought only a few hundred masochists would show up on Opera Square - that's how little hope I thought was left (...) As it turned out, I was wrong: some 200,000 people participated in the march. There still was hope. And if hundreds of thousands of people continued to hope, then someone had to organize their hope" (Blandiana 1991: 92). One day following the commemorative gathering on December 21, 1990, in University Square, the Liberal National Party, the NPP, and the Social Democrat Party of Romania united and formed the National Convention for the Instauration of Democracy (NCID). The Civic Alliance also merged with the Anti-Totalitarian Democratic Front, followed by the joining of the NCID with the AntiTotalitarian Democratic Front in December 1991 (Civic Alliance). As Zimmerman wrote a year after the University Square events, "Civic Alliance [a broad-based opposition group] which didn't exist a year ago, organized commemorative demonstrations. (...) These demonstrations were significant in that they showed Civic Alliance's capacity to organize and coordinate nationwide actions" (Zimmerman 1991: 96). These mergers formed the Democratic Convention of Romania (DCR). Emil Constantinescu became DCR's candidate, and his main credentials were not his political experience but the fact that he was "a university professor outside the circle of the political parties, linked with the University Square Phenomenon, and a member of important civil organizations" (Tariuc 1998). Constantinescu's electoral victory was celebrated at midnight on November 17 in University Square by 80,000 people waving flags and shouting, "We won." In his speech the same night, Constantinescu told the people who had 
gathered there: "In this square we conquered liberty. This square is kilometre zero for democracy in Romania" (Chiriac 1997: 38).

The formation of the DCR shows that the University Square movement did not vanish altogether with the protest itself. The University Square continues to be referred to as "a moral victory even if its goals were never fully attained" (Cesereanu 2003), and it is still considered symbolic of the beginning of democratization in Romania. If in the spring of 1990 the University Square protesters were framing their cause in such a way as to build a continuation with the 1989 Revolution, they were now framing "the defeat" of the University Square in glorifying terms. This process of "framing the defeat," as Kim Voss points out, consists of "constructing a 'fortifying myth' and explanation of defeat that linked current failure to future triumphs, keeping hope alive so that activists could mobilize support when new political opportunities arose" (Voss 1998: 139), This glorification of the University Square, in spite of its collapse, helped the opposition in the long run to organize and reorganize the newly formed DCR. The University Square Phenomenon, furthermore, preserved the University Square itself to always be ready for another demonstration. Thus, demonstrations, although they weaken in intensity, continued to take place in the University Square: for example, December 21, 1990; October 1991; April 26, 1992; December 1, 1993; December 16, 1993; November 25, 1994; February 1999, and June 2003. Also not without importance is the fact that the University Square Phenomenon continues to receive yearly coverage in newspapers and magazines such as Cotidianul, România Liberă, and Revista 22 under the heading "we must not forget." It is sufficient to say that the memory of the University Square survived and its identity became rearticulated into a democratic process that increasingly took the form of routine politics.

The traditional factors accounting for democratization were present in the aftermath of the University Square. First, the democratization of Romania was brought about by "some groups who wanted such a shift to take place and were willing to make vigorous efforts to effectuate it" (McAdam et al. 2001: 272). Second, these groups ? including the Civic Alliance, the Student League, the Group for Social Dialogue, and other organizations ? realized the need for a civil society that was, prior to this time, "muzzled and mutilated" (Călinescu and Tismăneanu 1991: 50). These new groups and organizations were thus fulfilling the need to bring forth "trust networks within society" (McAdam et al. 2001: 275). Third, they acted as counter-elites and saw themselves in opposition to ? and eventually became the official opposition of ? the government in power (McAdam et al. 2001: 268). The 
path to democratization, however, started in December of 1989 with an explicit desire to move away from the communist dictatorship. In its aftermath, some Romanians perceived the new provisional government as a threat, and they feared a return to communism before democracy had had a chance to materialize. However, the failure of University Square aided the cause of those who opposed the provisional government more through myth than if it had transformed into the second revolution the protesters had hoped for. In addition, part of the long-term ? or rather the very long-term ? implications of this episode of contention is the current pressure from various civil society organizations on the Romanian government for a lustration law with serious judicial repercussions. In their demands for decommunization and for "the trial of communism," civil society organizations continue to draw resources from the Proclamation of Timişoara and the 8th point that the University Square Phenomenon made famous (Cesereanu, 2005a). Moreover, during the 2004 electoral campaign, organizations like the League of Students and the Civic Alliance and Group for Social Dialogue converged to form the Coalition for a Clean Parliament. Though the primary focus was to eradicate the Parliament of corruption, the coalition included amongst its criteria for evaluating candidates the provision that candidates ought not to have been an agent of the former Securitate (Tismăneanu, 2005). This point resonates strongly with the 8 th point of the Proclamation of Timişoara.

The short-term political failure of the University Square fuelled the forming of coalitions that constituted themselves as political actors, and they remained so even when excluded from formal political power. Those coalitions created the beginning of routine politics in a society that for more than forty years witnessed only the "imposition of uniform governmental structures and practices through the government's jurisdiction" (McAdam et al. 2001: 268). Furthermore, the Civic Alliance, together with the other organizations that emerged from the University Square, played a crucial role in incorporating and expanding the newly formed trust network of the University Square by embodying the political identity and the goals of the University Square on their political or apolitical programs. Thus, a repertoire of contention that started with the 1989 Revolution was first adopted and then transformed during the University Square protest. Finally, with the election of 1992 and the DCR gaining 20\% of the vote in parliamentary elections (Popescu and Hannavy 2002), Romanian society witnessed the "dissolution of coercive controls supporting current relations of exploitation and opportunity hoarding" (McAdam et al. 2001: 257). Combined with the DCR victory in the 1996 election, it 
became clear that political inequality could be addressed. This does not mean that Romania is sheltered from a detour. It only means that the analysis of the University Square Phenomenon and its aftermath allows for the visualization of the rise of a new political identity through contention and the rapid consolidation of the same identity in routine politics. Furthermore, this study shows that the University Square Phenomenon was not an "experience from which the political opposition lost" (Georgescu 2004), as Former President Ion Iliescu affirmed recently, but rather it was an experience that served as a catalyst for the unification of the opposition and which contributed to its electoral success in 1996. It additionally contributed to the naissance of the first civil society organizations and the consolidation of democratic practices and principles in the long run. The University Square Phenomenon continues to be evoked as the mass protest which initiated de-communization (e.g. Cesereanu 2005b), a process which marks a society's attempt to come to terms with its authoritarian past in political as well as in social and cultural manners.

\section{CONCLUSION}

The University Square Phenomenon had a significant impact on Romania's post-1989 politics. As shown above, most of its impact ironically stems from its failure. The powerful identity of the University Square, however, survives to this day and many Romanians see this episode as a major learning experience in a country where older generations had to rediscover democracy, while the newer ones had to grasp its implications, both in its contentious and in its routine forms. This apparent learning process is best captured in the writings of a young Romanian: "At the time, I was nine, going on ten. As my parents attended the meeting, I did the same. I shouted, though I did not quite understand what it was I shouted. But there, in the University Square, I learned freedom existed and was worth fighting for. (...) I learned I could say NO to the government. I learned about common identity, about the magic of songs. (...) I learned about the power of masses and mass action" (Conovici 2004). To some extent, this romantic view also aided the University Square's six-week marathon protest in forging a lasting repertoire of contention that now stands on its own.

As this article suggests, the analysis of social movements does not have to end with the movement itself because the latter can have long-term political implications, which the study of social movements can make explicit if it reaches past the contentious episode itself. From this perspective, the analysis of the University Square Phenomenon 
sheds light on the issue of "how social movements matter" by stressing the impact of this contentious episode on Romanian party formation and political culture. Borrowing from Dynamics of Contention, this analysis backs the claim that identity formation and contentious repertoires can matter well beyond the decline of a specific contentious episode. In the future, scholars could further explore this issue by stressing the manner in which social movements and contentious episodes can affect political culture and partisan politics and not only policy outcomes, as is frequently the case in the existing sociological literature. Overall, this article shows that, although clean streets and a return to routine politics point to the end of a concrete protest episode, its symbolic and political driving force may survive by other means for a long period of time.

Contact address:

Julia Brotea, Department of Political Science, Carleton University

(E-mail: jbrotea@connect.carleton.ca)

Daniel Béland, Department of Sociology, University of Calgary

(E-mail: dbeland@ucalgary.ca)

\section{NOTES}

[1] Acknowledgement: The authors wish to thank Angela Kempf and Ali Rezaei for their comments on earlier drafts of this article.

[2] On the miners' movement see Gledhill, 2005.

[3] The miners from the Jiu Valley continue to represent a threat to Romania's attempt to democratic consolidatiton The miners were largely aided in their process of forming a participant identity by the priviledged status they enjoyed during the communist era and the subsequent legimiation Iliescu bestowed upon them after 1990. The events from June 1990 mark the third time the miners arrived in Bucharest, while February 1999 marked their sixth arrival in the capital. (Vasi, 2004; Fonta, 1999)

\section{REFERENCES}

“Alianţa Civică" (Civic Alliance). 2004. "Istoric." < http: / / www.aliantacivica.ro/> Amenta, Edwin. 2006. When Movements Matter: The Townsend Plan and the Rise of Social Security. Princeton: Princeton University Press.

Amenta, Edwin and Neal Caren. 2004. "The Legislative, Organizational, and Beneficiary Consequences of State-Oriented Challengers," in The Blackwell Companion to Social Movements, David A. Snow, Sarah A. Soule, and Hanspeter Kriesi, eds. London: Blackwell.

Anderson, Benedict. 1991. Imagined Communities (revised edition). London: Verso. 
Arendt, Hannah. 1990. [1963] On Revolution. London: Penguin Classics.

Bellu, Dorelian and Andrei Badin. 2005. "Essential: Let us not Forget the University Square," Evenimentul Zilei, (22 Aril).

Blandiana, Ana. 1991. “Interview with Ana Blandiana," Uncaptive Minds 4(3): 91-94.

Călinescu, Matei and Vladimir Tismăneanu. 1991. “The 1989 Revolution and Romania's Future," Problems of Communism 40(1): 42-59.

Cesereanu, Ruxandra. 2003. "Fenomenul Piaţa Universităţii," Revista 22 (6 May). <http:/ / www.revista22.ro/ html/index.php?art=445\&nr=2003-05-12>

Cesereanu, Ruxandra. 2005a. “Golania după 15 ani," Revista 22.

Cesereanu, Ruxandra. 2005b. "Proclamaţia de la Timişoara şi legea lustraţiei," Revista 22.

Chiriac, Marian. 1997. "The Opposition Takes All," Uncaptive Minds 9(1): 35-40.

Conovici, Iuliana. 2004. "The Kindergarden of Our Hopes." (26 March) $<$ http:/ / www.isha-international.org/ carnival/vol2/issue35/ conovici_i.htm>

Dabija, Tatiana. 2007. "Imnul golanilor liberi," ("The Anthem of Free Thugs"), Evenimentul Zilei, (16 June).

Denis, Deletant. 2000. "Ghosts from the Past: Successors to the Securitate in PostCommunist Romania," in Post-Communist Romania Coming to Terms with Transition, Duncan Light \& David Phinnemore, eds. New York: Palgrave.

Diani, Mario. 2001. "Social Capital as Social Movement Outcome," in Beyond Tocqueville: Civil Society and the Social Capital Debate in Comparative Perspective, eds., Bob Edwards, Michael W. Foley, and Marino Diani. Hanover, NH: Tufts University Press, 207-221.

Fonta, Vlad. 1999. "Valea Jiului - Un Caz Atipic in Economia Romaneasca," Sfera Politicii (Institute of Political and Economic Research together with the Foundation "Societatea Civila.") No. 67.

Gelb, Joyce and Vivien Hart. 1999. "Feminist Politics in a Hostile Environment: Obstacles and Opportunities" in How Social Movements Matter, eds., Marco Giugni Doug McAdam and Charles Tilly. Minneapolis: University of Minnesota Press. 149-82.

Georgescu, R. 2004. "După 14 ani de la reprimarea violenta a Pieţei Universităţii Ion Iliescu îi transformă pe 'golani' in 'corpuri străine'" ("After 14 years from the violent suppression of the University Square. Ion Iliescu transforms the 'golani' in 'alien bodies.'”), România Liberă (22 May).

Gheorge, Gabriela and Huminic, Adelina. 1999. "Istoria Mineriadelor din anii 1990 1991" ("History of the Miners from the Years 1990-1991"), Sfera Politicii, Institutul de Cercetări Politice şi Economice împreună cu Fudaţia "Societate Civilă," No. 67.

Giugni, Marco G. 1998. "Was It Worth the Effort? The Outcomes and Consequences of Social Movements," Annual Review of Sociology 24: 371-393.

Giugni, Marco, Doug McAdam and Charles Tilly (eds). 1999. How Social Movements Matter. Minneapolis: University of Minnesota Press.

Gledhill, John. 2005. "States of Contention: State-Led Violence in Post-Socialist Romania," East European Politics and Society 19(1): 76-104. 
Hickman, John. 1998. "Reporting Romania: A Content Analysis of the New York Times Coverage, 1985-1997," Eastern European Quarterly 32(3): 395-409.

Milin, Miodrag. 1990. Timişoara 15-21 decembrie '89, Timişoara: Timişoara.

McAdam, Doug, Sidney Tarrow, and Charles Tilly. 2001. Dynamics of Contention. Cambridge: Cambridge University Press.

Mische, Ann. 2003. "Interventions: Dynamics of Contention," Social Movement Studies 2: 85-96.

Mungiu, Alina. 1996. "Intellectuals as Political Actors in Eastern Europe: The Romanian Case," Eastern European Politics and Society 60(2): 333-64.

Osmani, Patricia. 1997. "Law and Nation in Post-Communist Romania," Institute on East Central Europe. Working Paper.

Paler, Octavian. 1990. "The Romanian Elections: A Dangerous Victory," Uncaptive Minds 3(3): 11-12.

Peterson, Abby. 2002 "Dynamics of Contention," Acta Sociologica 45(4): 323-30.

Popescu, Mariana and Martin Hannavy. 2002. "Romanian Election Results," Project on Political Transformation and the Electoral Process in Post-Communist Europe. Colchester: University of Essex. <http: / / www.essex.ac.uk/ elections/>

Proclamaţia de la Timişoara (The Proclamation of Timişoara) (1989),

<http:/ / www.timisoara.com/timisoara/ rev/ proclamatia.html> (23 August 2004).

Roşca, Ioan. 1996. "Acum 5 ani, Contrarevoluţia..." ("5 Years Ago, The Contrarevolution...") Asymetria Revue Roumaine de culture, critique et imagination. $<$ http:/ / www.asymetria.org >

Roper, D. Steven. 2000. Romania: The Unfinished Revolution. Amsterdam: Overseas Publishing Association.

Siani-Davies, Peter. 2000. "The Revolution after the Revolution," in Post-Communist Romania Coming to Terms with Transition, Duncan Light and David Phinnemore, eds. New York: Palgrave.

Steinberg, Mark W. 2004. "When Politics Goes Pop: On the Intersections of Popular and Political Culture and the Case of Serbian Student Protest," Social Movement Studies 3 (1): 3-31.

Sterian, Valeriu. 1990. "Nopţi" (Nights) [Music Album]. Bucharest: Compania de Sunet \& Metropol Music.

Tariuc, Alexandru. 1998. "PNŢCD - Un partid cu Istorie şi Viitor," ("NPCDP-A Party with History and Future"). Institute of Christian Democrat Studies.

Tarrow, Sidney. 1994. Power in Movement: Social Movements, Collective Action and Politics. Cambridge: Cambridge University Press.

Tilly, Charles. 2002. Stories, Identities, and Political Change. Maryland: Rodman and Littlefield Publishers, Inc.

Tilly, Charles. 1986. The Contentious French. Cambridge: Belknap Press.

Tindall, David. 2003. "From Structure to Dynamics: A Paradigm Shift in Social Movements Research," Canadian Review of Sociology \& Anthropology 40(4): 480-8.

Thompson, Mark and Philipp Kuntz. 2004. “Stolen Elections: The Case of the Serbian October," Journal of Democracy 15(4): 159-72.

Tismăneanu, Vladimir. 1990. “Homage to Golania,” New Republic 203(5/6): 16-19. 
2005. "The End of Postcommunism in Romania," Journal of Democracy 16(2):146-62.

Vasi, Ion Bogdan. 2004. "The First of the Working Class: The Social Movements of Jiu Valley Miners in Post-Socialist Romania," East European Politics and Societies 18(1): 132-57.

Voss, Kim. 1998. "Claim Making and the Framing of Defeats: The Interpretations of Losses by American and British Labor Activists, 1886-1895," in Challenging Authority: The Historical Study of Contentious Politics, Michael P. Hanagan, Leslie Page Moch, and Whyne te Brake eds. Minneapolis: University of Minnesota Press.

Zimmerman, Harry. 1991. "Interview with Harry Zimmerman," Uncaptive Minds 4(3): 95-100. 